\title{
From the Closet to the Wallet: Pawning Clothes in Renaissance Italy
}

MARIA GIUSEPPINA MUZZARELLI

University of Bologna

\begin{abstract}
Dans l'Italie de la Renaissance, ce sont les vêtements qui sont le plus couramment mis en gage par ceux qui cherchent à obtenir des prêts auprès des banquiers juifs et du Monte di Pietà. Des robes, des chemises et même des chaussures sont mis en gage, et les vêtements féminins le sont plus souvent que les vêtements masculins. Cet article examine les divers types de vêtements que les emprunteurs - hommes et femmes - offraient de mettre en gage, dans le but de déterminer leur qualité et leur valeur, et de cerner ainsi l'identité de ces clients. En prenant appui sur cette thématique, cet article montre comment l'analyse des changements de types de vêtements mis en gage à la fin $d u X V^{e}$ et au XVI siècle peut nous aider à mieux comprendre les changements de motivations et d'identités des emprunteurs de cette époque.
\end{abstract}

$\mathrm{T}$ he Italian monti di pietà emerged in the second half of the fifteenth century to provide small sums of money lent on pawn to individuals who could not pay the high interest rates set by Jewish or Christian private bankers. ${ }^{1}$ In towns and cities across central and northern Italy, monti di pietà organized themselves according to similar standardized sets of rules that were adapted to the peculiar conditions of different local situations. These rules were not very different from those of the private banks. The principal differences were that in theory - if not always in practice - the monti di pietà lent only to private citizens at a very low interest rate (usually around 5 percent), and served only the moderately poor (as opposed to the indigent). The statutes of the Monte di Pietà of Reggio Emilia (founded in 1494) expressed this succinctly:

There should be lending only to those people who come to borrow because of their need and necessities, intending one per family ... and those persons must clarify openly whether they want it for themselves or 
for another, and [then] declare whom, and they are also obligated to swear that they wish it for their own use and for their necessities. Beyond this, if you lend and if someone takes it to invest or to trade or make other superfluous or indecent purchases, then they must lose their pawn. ${ }^{2}$

The statutes in Parma (founded in 1488) stipulated that money could only be lent for the use and necessities of the poor ${ }^{3}$ while those of Spoleto (founded in 1491) noted, "lend only to the poor and needy of the city and contado of Spoleto, to the limit of 3 florins per eight months and with receipt of a pawn valued at twice the loan."

The goal was relatively clear: those founding and supporting monti di pietà intended them to be of use in meeting the urgent needs of poor people only, and not for the convenience of the population at large. However, it was and is difficult to define accurately who was considered poor; and in any event, as we can see from the article by Paola Pinelli in this collection, those in charge of local monti sometimes bent the rules by lending to individuals who were relatively well-off. One avenue of approach is to move beyond the regulations on the loans themselves and focus on the rules and practices around the pawns that borrowers had to leave on deposit. In this article, we will examine some sources in which pawns were registered in order to gain a better idea of those whom the monti helped. We will look at three separate sets of documents: a list of pawns sold in Perugia in 1469, many of these being the unsold remnants from an auction held the year before; ${ }^{5}$ a list of pawned items that were sold in an auction by the Pistoia Monte di Pietà from June to September $1491 ;^{6}$ and a registry of pawns taken by the Urbino Monte di Pietà in 1492-93. ${ }^{7}$ By moving the study of the monte beyond the balance sheets and statute books and into the realm of material culture, we get a better idea of how flexibly "poverty" was interpreted, and how goods served as the repository of value for families up and down the social scale. These same goods and their progressive circulation down the social ladder - from luxury goods, to gifts, to payments, and eventually to pawns - also give us a new tool for tracking social relations between distinct and overlapping sets of patrons and clients at both the upper and lower ends of the social range.

Borrowers pawned everything from jewels to tools, sheets, and belts, but it was clothes above all that they brought to their local monti di pietà. As a result, registers of pawns offer a good deal of information about the social movement 
of clothes that is useful for reconstructing the history of fashion. Many ornate and expensive garments, when used and consumed or not well conserved, were passed on by their wealthy owners to servants, clients, or second-hand dealers who then sold them to poorer people. ${ }^{8}$ As a result, our sources list many formerly costly items that were effectively "declassed" and traded at much reduced values. For the poor, second-hand items of clothing that had once been sumptuous and expensive continued to represent important repositories of value which in case of necessity could be pawned at the monte. This put the clothing back into broader circulation. From the late Middle Ages onwards, second-hand markets flourished and many second-hand dealers bought their wares at the monti auctions. ${ }^{9}$

Monte statutes across northern and central Italy commonly addressed the responsibility of monte officials to conserve pawned objects, defining who had to guard, save, and see to them (ghuardare, salvare et provedere), and even requiring the presence of a cat to ensure that mice didn't destroy cloth and garments. Clients had to pawn items that were worth one-half to two-thirds more than the sum loaned. Most sets of rules included lists of what could or could not be pawned: clothing and household items were acceptable, while religious objects such as crosses or bibles were not. Stolen items were explicitly refused.

Every client received a receipt that had to be presented when money was repaid. Clients had twelve to eighteen months to return the funds they had borrowed; if the money wasn't repaid, their pawned objects were auctioned off, with a trumpeter going through the town or city to announce the start of the public auction. If the sums realized through the sale of the pawned item exceeded the amount of the loan plus accumulated interest (generally 5 percent) the excess (sopravanzo) had either to be returned to the client or spent on the needs of the poor generally by being turned over to other charities or pious works. Pawned objects themselves could not be sequestered by the authorities.

Everything that was pawned had to be recorded in a register, and statutes typically provided for recourse to an expert when it came to estimating the value of specific item such as textiles, belts, and rings. ${ }^{10}$ In fulfillment of this regulation, the Monte of Reggio Emilia maintained seven distinct volumes for the separate registration of all operations. This very detailed record keeping pointed to the monte's public commitment to precision and transparency, and 
stood in sharp contrast to those private bankers who sometimes quite deliberately destroyed their papers. ${ }^{11}$ One of Reggio Emilia's seven volumes recorded all of the loans registered by the master (massaro) with the name and surname of the client, the sum borrowed, and a list of all the pawned items including descriptions of their nature and condition (qualitade de la cossa impegnata). ${ }^{12}$ Ledgers of this kind provide a great deal of information beyond mere descriptions of pawned objects.

Some monti had extensive sets of rules while others adopted only short texts. The former often include specifications on the maximum amount that could be loaned. A low ceiling confirmed that the institution intended to sustain many people with small loans rather than operate as a general banking service, offering credit not only to poor citizens for basic necessities but also to artisans and merchants for their business activities (some statutes explicitly forbade lending to merchants altogether). So, for example, in Pistoia the maximum loan the monte could offer was seven florins, in Perugia it was initially six and then seven florins, in Terni five, in Spoleto and Gubbio four, and so on. ${ }^{13}$ While the differences between local economies and currencies make direct comparison difficult, we have some idea of the purchasing power that this represented. A bushel-sized measure of wheat (staio) in Pistoia cost 30 soldi in the 1490s, while a small barrel of oil (quaderno) cost 120 soldi. ${ }^{14}$ At these prices, Pistoians who borrowed the maximum amount permitted by the monte could then conceivably purchase enough food to carry a family for a month or more.

The auction lists from Perugia and Pistoia and the Urbino register allow us to move beyond the prescriptions found in statutes and determine what kinds of goods the poor used as flexible repositories of value. These sources allow us to track by the week, month, or year the number of items pawned, and to compare what value they held. We can distinguish the quality of different objects such as garments, linen, jewellery, household wares, and weapons. We can discover clients' identity, gender, origin, and sometimes their profession. We are also able in some cases to determine if and when clients reclaimed pawned objects and the interest rates they paid.

As already noted above, items of clothing were the most commonly pawned objects. These were seldom new, and the Urbino register and Pistoian and Perugian auction lists include specifications on their physical condition: whether they were heavily worn, whether they had rips or tears, whether moths 
had eaten holes or vermin had chewed the edges. Registries of this kind allow us to prepare a glossary with the local names and values of different cloths and items of clothing, and to identify the prevalent customs and fashions in different towns in the same period, singling out the more significant characteristics of the items pawned more frequently. We can imagine which clothes moved in the streets of the town, and which styles, fabrics, and colours were more popular. By far the most commonly pawned item was the long and rather large woman's garment known as the gamurra or camurra (with local variant spellings as camurre, camore, camure, or camorre). It was open in the front and decorated with buttons and sleeves of various colours and fabrics that were often detachable.

Since monte statutes typically forbade lending large sums, it is rare to find objects and clothing of great value like the kinds of sumptuous garments found in contemporary portraits; ${ }^{15}$ rare, but not unknown, and the exceptions we encounter might be seen as signs of questionable financial management on the part of either the borrower or the individual monte. In reality, the definition of the needy poor (poveri necessitosi) was generic and highly elastic. Beyond that, we must remember that while the registrations of Urbino concerned pawned items, those of Pistoia and Perugia recorded auctioned objects. This difference obviously complicates the comparison of prices.

In Perugia, where the maximum loan at the time of our 1469 register was seven florins, we find a few items that were just barely within the limit. A certain messer Francesco di Ludovico Baglioni pawned a book for six florins and 30 soldi, while other members of the same important family also took out loans. Madama Bianciola pawned a velvet camurra for the same amount, while messer Giovanni pawned a black fabric with silver embroidery ("cum ariento dorato e uccellato") for one florin and 75 soldi. ${ }^{16}$ Yet these were exceptional items. The vast majority of items pawned in Perugia were worth only a few soldi. Here, as practically everywhere, women's clothes predominated among the pawned objects, followed by men's items, fabrics, housewares, books, tools, furnishings, and weapons. Jewellery was almost completely absent.

In Pistoia, by contrast, the most prominent items in the list of goods auctioned from June to September 1491 were housewares: well over half (399 of 680) were table cloths, sheets, and towels. There were also 164 items of clothing, and 52 pieces of jewellery. ${ }^{17}$ The most common pieces of clothing were capes 
of different kinds (26 cioppe and 26 mantelluzzi), the ubiquitous gamurra (17) and decorated belts (22), but the lists also contained a few examples of clothing worn in public like the long gowns or coats know as lucchi (6) or giornee (3). Among the less plentiful items we find various items such as the small jackets known variously as giacchette (5), cappette (4), sottanelle (2), and guarnneli (2). ${ }^{18}$

In contrast to the Urbino register, the Pistoia auction list only rarely refers to clothes as being either old or worn out, and most items sold for between one and five florins. The maximum sum obtained from the auction in Pistoia was seven florins and 53 lire, and it was raised through the sale of a group of objects as a single lot: a long coat (lucco) made of dark red wool (panazzo) and light silk taffeta, one green and one red belt, and a woman's small jacket in black satin. ${ }^{19}$ Objects were often auctioned in lots in this way, a sign that most items individually were not of particularly great value. Most of the unreclaimed objects sold in the monte's auction went for relatively little, and even more important items might sell for as little as a florin. This was the price for a green gamurra with rosy-coloured sleeves (it was usual for the garment to have detachable sleeves made of different kinds of fabric). Another item selling for only a florin was a woman's coat (cioppa) made of the modest fabric known as perpignan; this was an over-garment which, when worn with the gamurra, represented a complete winter outfit. A wide and highly-worked velvet tunic (cotta di velluto affigurato) which clearly had originally been very important and expensive, sold for the same relatively low price, a sign that it was evidently now old and in bad condition. ${ }^{20}$ Yet not all items were cheap. A women's overcoat (cappa) with damasking in silver (damaschino d'argento) fetched the higher sum of five florins, and a gamurra paonazza (probably of a dark red wool but it could also indicate a more precious fabric) with a train also sold for more, though we can only speculate who might have bought it. Clearly this wasn't a common cloth for daily use, but in its second or third life it belonged to a common person or was pawned by people who were not of low social standing. ${ }^{21}$

While many of these items of clothing were for women, women appeared as clients in only seventeen of the Pistoian cases, and in some cases it was the same women coming back a second time. This represented only 5 percent of total registrations, or less than half the number found in the Urbino documents, where over the eleven month period, 64 of the 510 items (12.5 percent) were presented by women. ${ }^{22}$ 
The information in the Urbino monte's registers is most useful for the history of fashion since it clarifies the use of clothing and allows us to reconstruct the costumes of people from the lower and middle social classes about which we have few visual or literary sources. We should recall that the Urbino court was among the most fashionable in Italy at the time; and with the common custom of passing clothing on to servants, even those from the lower social orders might have items of clothing that were - or had once been - quite lavish and extravagant. The lists of pawned clothing in the Urbino monte records can be compared to those in notaries' documents, such as last wills and testaments or dowries. Most registered items were in bad condition, and were recorded as old, stained, frayed, moth-eaten (tinghiati), or cut.

Almost 40 percent (185) of Urbino's pawned items were articles of clothing. The majority (82) were the women's basic garment known here as the camurra or gamurra that we have already seen in Perugia and Pistoia, although there were none of the outer garments known as cioppa with which these were frequently paired. ${ }^{23}$ The Urbino register did however note other overgarments used in the same fashion, such as 33 of the simple mantles known as tabarri and tabarretti. These, similar to capes, were made of simple fabric, and the registers have various other outer garments of this type, including 27 short capes going under such names as mantelli, mantelletti, and mantelline. There are also men's jackets (giupponi) (15), men's and women's skirts (9), women's everyday clothing (guarnelli) (6), jackets and coats (giornee) (3), and one of the tight-fitting jackets known as guardacuore. There were also three unspecified items.

Beyond textiles, the Urbino register included many belts (61); these were generally decorated, often with gilding and precious stones. Among the 33 other items of jewellery, we find twenty rings (anelli e anelletti), three more plain rings known as verghette, two sapphires set in gold, four strings of coral (corde di corallo), two strings of pearls, and two rosaries (agnusdei). ${ }^{24}$

These items were rare; as in Pistoia, the majority of objects pawned in Urbino provided the collateral for only small loans at best. The value of the various objects was recorded in either bolognini or in florins, one florin being worth approximately 40 bolognini. The largest loans recorded were for four florins, and these were most often given for jewellery, such as a gold ring with a precious stone, for lots such as four gold rings and two silver spoons pawned together, or for other items in or decorated with precious metals, such as a silver cup and a decorated belt, a silver cup and a winter cloak (tabarro), or a belt 
with a buckle and decorative point or tip. ${ }^{25}$ The value of jewellery varied greatly: a string of small pearls was pawned for 60 bolognini, while a three-ounce string of coral gained 40. And while a gold ring with a dark red gem (con balacio) gained the most at four florins, another nine carat gold ring with a gemstone called a grenade (con una granata) brought in only twelve bolognini, while a thirty-six carat sapphire set in gold brought in $40 .{ }^{26}$

In a few cases clothes could fetch this same sum, but they were clearly exceptional. One example was a winter cloak (tabarro) of precious fabric (paonazzo di grana) with a different green flounce, free of stains and adorned with numerous decorations, including 56 silver decorative eyes and hooks to close it in place of buttons (presette cum li gangeri). There was a rosy-coloured camorra and also a velvet one. These had no doubt once been beautiful objects, but their state of conservation was decidedly poor by the time they ended up in the Urbino registry. ${ }^{27}$ With clothing, it was still more common to find clients securing the larger loans of four florins by bringing in varied lots of items, including lengths of cloth, like the borrower who brought in just over two metres of satin weave silk (raso alessandrino), almost eight metres of fine tablecloth woven of fine fabric from Reims (tovaglie di renso), and one boy's outfit. Another client pawned a black velvet belt with a buckle and decorated tip with embroidered writing (puntale con scritta ricamata) which read "virtus omnia vincit" or "virtue conquers all," and a handkerchief embroidered with metal thread. ${ }^{28}$

If we focus our study of clothing on the 82 camorre or gamurre pawned, we can learn a great deal about styles, fabrics, colours, and values in Urbino. Here, as elsewhere in Italy, these were the items of clothing most often pawned, and they would appear in a wide range of colours and fabrics. Some were simple cloth dyed green, black, sky-blue, turquoise, maroon, and silver. Others include a length of thin woollen cloth with diagonal weave (saio) dyed pink, lengths of velvet or satin in black, dark red, or light red, and undyed lengths of the modest cloths known as monachino and bruschina. Of the 82 camorre pawned, the majority were described with variations on a sky-blue colour (e.g., turchina, de cilestro, cilestra, and de panno cilestro). Yet since the sleeves and body of the garment were frequently of a different colour, the combinations of colours tell us a great deal about contemporary styles. The most common colours and textiles for the detachable sleeves included rose, black velvet, or dark red (pavonaza), or a combination of red and black. In more than one case, sky-blue camorre were 
decorated with green flounces, which seems to have been an enduring style of the period.

The camorre were the pawns for loans ranging from as little as twelve bolognini to as much as four florins. Here again, they often came as part of larger lots of clothing, and while the condition of the item usually determined the size of the loan, there may well have been other personal factors involved since values could fluctuate widely. ${ }^{29}$ One of the cheaper camurra, a frayed and stained garment of black woollen cloth with red sleeves, fetched the same twelve bolognini as another without sleeves but obviously in better shape. Another of black wool that was used, stained, and holed brought eighteen bolognini, while one with sleeves of black velvet that was broken, threadbare, and moth-eaten in many places brought twenty. This last garment was wrapped in a light fabric (pannicello biancho), a description that appears on more than one occasion and that reveals how people of the time conserved and presented their garments. This fabric sheath of light cloth wrapping was often pawned along with the clothing. The same method of conservation was common for belts. ${ }^{30}$ The smallest amount obtained for an article of clothing was ten bolognini, which was given for a worn man's cape of brown cloth (di panno tanè tutto logoro) and also for a damask belt that was worn and damaged. ${ }^{31}$

While once fashionable and expensive items of clothing that had been reduced to a poor state were the most common kind of pawn that borrowers brought to Urbino's monte di pietà, other textiles also appear frequently. Bed sheets were not uncommon and carried various values ranging from eight to 40 bolognini depending on the size, fabric, and condition: $6^{1 / 2}$ braccia of a middleweight linen (grossello) were worth eight bolognini, while a thin fifteen-braccia sheet was worth fourteen. Those bringing in sheets often brought in lengths of unworked cloth as well. One borrower pawned a pair of sheets and three bolts of fabric for eighteen bolognini, while another gained 40 bolognini for a bolt of cloth that was $26 \frac{1}{2}$ braccia. ${ }^{32}$ By comparing pawn registrations, we can see that one braccia of middle-weight linen was usually worth one-and-a-half bolognini, while a thinner weight could be worth up to two. ${ }^{33}$ The wide range of very specifically-described cloths allows us to work out a comparison of the contemporary values for different types of cloth: the light weight black satin (raso nero) and the light silver-coloured cloth known as panno argientino were most valuable at twelve bolognini per braccia, while the cheapest cloths were 
white fustian (fustagno bianco) and linen, at roughly one-and-a-half bolognini per braccia.

Another commonly pawned item of clothing which is perhaps a little more surprising was the belt. The cheapest belt brought in only nine bolognini, just a bit less than a pair of worn-out socks. A velvet or brocade belt with buckles and decorations might bring in as little as fifteen bolognini or as much as two florins. Decorations in enamel or fashioned with short lengths of metal (con smalti e spranghette) could push the value up to 20,25 , or 40 bolognini depending on the quality and quantity of the work. Belts, like clothing, were frequently described as being wrapped in some kind of light material, either pezza di rosato or taffettà or even a kind of handkerchief (mucichino). The highest valued belt was of black velvet with a buckle that featured a diamond and 25 gilded decorative lengths of metal; the miller who pawned it received four florins. Gilded metal rods, bells, and pins and short franges (presette e frangette) most commonly decorated the pledged belts. The weight of decorations such as the gilded rods varied from three to five ounces, and when they were pure or gilded silver they had a direct bearing on the belt's value. ${ }^{34}$ For purposes of comparison, a silver cup weighing six ounces was worth 100 bolognini. Urbino's borrowers brought in silver cups of different weights and decorations, sometimes including gilded rims, for sums varying from 70 bolognini to four florins, which tells us that the value of silver varied from ten to twenty bolognini per ounce. ${ }^{35}$

Hence a mid-priced belt, worth 40 to 60 bolognini, could have fetched the same price as a lined camurra without sleeves. The most modest item pawned at this point in Urbino was a pair of worn-out socks that a slave woman, Maddalena, presented in return for a loan of six bolognini. We move further and further into the inner life of the household: fourteen bolognini for a large baking tin, and eight for a pillow. ${ }^{36}$

From a pair of socks to a precious belt to a baking tin, the objects within the household constituted a key resource for many people in desperate situations. ${ }^{37}$ We can see that outfits, and clothing in general, were among the items most frequently pawned. An examination of the terminology used in the lists and registers of Perugia, Pistoia, and Urbino helps us follow both the furnishing and the language of the household, while the terms used to describe the various pawned articles and their actual descriptions allow us to track the popular styles, colours, and accessories of the period. These same registries and auction 
lists also give us an idea of the value of items of clothing, fabrics, household goods, and jewellery owned by people of few resources. As a result, these objects help us to decipher a larger social world. ${ }^{38}$ The pawns presented at the various monti di pietà across Italy tell us about the context of scarcity in which used clothes, heavily worn and holed, were still valuable and destined to have long lives. Few households had many surplus items lying about that could be pawned in times of need, yet in a sense households were nonetheless full of pawnables, and this constituted a reserve for the poor. ${ }^{39} \mathrm{~A}$ poor woman's camurra that had previously belonged to someone else was often the only object of value in her household. Once pawned, it allowed her to cover unanticipated and necessary expenses. The object that made a woman look fashionable thus became, for the family, something to hold onto for those hard times when money was in short supply. From good taste to family lifesaver, women's garments spoke volumes about social status while also serving as liquid assets or a financial reserve that could guard against unanticipated expenses and possible shifts in social conditions.

Baldassarre Castiglione observed that "an outfit is of no small importance to the imagination of the wearer." ${ }^{30}$ Women were at the centre of the economic exchange described above, but they were not protagonists. Signs of privilege were displayed on their bodies and then removed, regardless of any personal importance they may have had in the woman's life or imagination, or even of the fact that they may have been part of the women's dowries and so were objects that tied them to their family of origin. Behind the clothes and personal objects that we find circulating through the economy, there is a much longer history of family dynamics, artisanal ability, commerce and compensations, style and want, a desire to be set apart, customs and reuse. ${ }^{41}$ There is also a painful story of needy people for whom the monte offered immediate solutions through the pawning of gowns, capes, or belts that might then be resold. The garments listed in registers and auction lists went from being prized possessions to merchandise, often frayed or mouse-eaten, which fetched only small sums that allowed a family to survive crises, thanks to the sacrifice of the women who had previously owned them. Often these crises were momentary and the pawned items were subsequently reclaimed. However, many pawned objects never returned to their original owners. In these cases, thanks to continued money problems on the part of these owners, the garment, ring, belt, or sheet might continue to circulate further and further down the social ladder as poor 
families managed their ongoing negotiation between the closet or clothes chest and the wallet.

\section{Notes}

1. M. G. Muzzarelli, Il denaro e la salvezza. L'invenzione del Monte di Pietà (Bologna: il Mulino, 2001).

2. "Se habia ad imprestare solo a quelle persone che per loro bisogno et necessitade venessero ad impegnare intendendo uno per famiglia ... et le quale persone debano chiarire apertamente se vogliono per se o per altro et dechiarare per chi et anche siano obbligati a zurare che voleno per uso suo et per sua necessitate. $\mathrm{Ni}$ altramente se presti et si alcuno ni tolesse per guadagnare on per mecadare o per fare altra spesa superflua et non condecente se Intenda hauere perduto il suo pegno," in A. Balletti, Il Santo Monte della Pietà di Reggio nell'Emilia (Reggio Emilia: Stefano Calderini e Figlio, 1894; reprint Reggio Emilia: Cassa di Risparmio di Reggio Emilia, 1994), p. 135.

3. "in uso e bisogno dei poveri," in L. Grandinetti, Il Monte di Pietà di Parma. L'istituto attraverso cinque secoli di vita cittadina (Parma: Banca del Monte, 1976), p. 27.

4. "prestare solum ad poveri et bisognosi della ciptà et contado de Spoleti per fine alla quantità de fiurini tre per octo misi...colla receptione delo pegno sufficiente valente el doppio," in M. Sensi, "Fra Andrea da Faenza istitutore dei Monti frumentari," Picenum Seraphicum IX (1972), pp. 162-257, 234.

5. Archivio di Stato di Perugia, Miscellanea di computisteria, n. 3, cc. 3r-18r. See transcription in S. Majarelli and U. Nicolini, Il Monte dei poveri di Perugia. Periodo delle origini (1462-1474) (Perugia: Banca del Monte di Credito, 1962), documento n.14, pp. 337-58.

6. Archivio di Stato di Pistoia, Atti civili, filza 34, Quaderno della vendita dei pegni del Monte di Pietà di Pistoia (19 giugno-23 settembre 1491). See transcription in I. Capecchi and L. Gai, Il Monte della Pietà a Pistoia (Firenze: L. S. Olschki, 1976), appendice documentaria, pp. 223-47, documento n. 4.

7. Archivio di Stato di Urbino, Fondo Monte di Pietà, Libro del depositario 1492-1493. My thanks to Giulietta Gheller for this reference. For more on this institution, see G. Gheller, "I capitoli del Monte di pietà di Urbino del 1468 e le loro specificità nell'orizzonte delel coeve fondazioni di Monti Pii," in I Monti di Pietà 
fra teoria e prassi. Quattro casi esemplari: Urbino, Cremona, Rovigo e Messina, ed. M. Carboni and M. G. Muzzarelli (Bologna: Clueb, 2009), pp.1-65.

8. P. Allerston, "L'abito come articolo di scambio nella società dell'età moderna: alcune implicazioni," in Le trame della moda, ed. A. G. Cavagna and G. Butazzi (Roma: Bulzoni, 1995), pp. 109-24; P. Allerston, "L'abito usato," in La moda, Storia d'Italia, Annali, 19 (Torino: Einaudi, 2003), pp. 561-81.

9. C. Collier Frick, "The Florentine Rogattieri: Second Hand Clothing Dealers and the Circulation of Goods in the Renaissance," in Old Clothes, New Looks: Second Hand Fashion, ed. A. Palmer and H. Clark (Oxford: Berg, 2005), pp. 13-18; H. Jenss, "Second Hand Clothing," in Berg Encyclopedia of World Dress and Fashion, 8, West Europe, ed. L. Skov (New York: Berg, 2010), pp. 171-75.

10. "tessuti, cincture, anelle, zoglie et simile cosse," in Balletti, p. 137.

11. M. Fornasari, Il "Thesoro" della città. Il Monte di Pietà e l'economia bolognese nei secoli XV e XVI (Bologna: Il Mulino, 1993), p. 160.

12. Balletti, p. 138.

13. Muzzarelli, Il denaro, pp. 199-200.

14. The staio measured 25.92 litres, and the quaderno 14.83 litres. For these measures and their value, see D. Herlihy, Medieval and Renaissance Pistoia: The Social History of an Italian Town, 1200-1430 (New Haven: Yale University Press, 1967), pp. xix, 123-28. In the 1490s the florin was worth roughly 140 soldi. R. A. Goldthwaite, The Economy of Renaissance Florence (Baltimore: The Johns Hopkins University Press, 2009), p. 613.

15. Muzzarelli, Il denaro, pp.198-204.

16. The list records that the book pawned by Francesco was "called Lattanzio" (chiamato Lattanzio); this was most likely a work or compilation of the ancient Roman author Lucius Caelius Firmianus Lactantius (ca. 260-326). Majarelli and Nicolini, pp. 348, 352.

17. Capecchi and Gai, pp. 128-29.

18. Capecchi and Gai, p. 129.

19. "giacchetta di rasa nera," in Capecchi and Gai, p. 226.

20. For the clothing styles and fabrics see M. G. Muzzarelli, Guardaroba medievale. Vesti e società dal XIII al XVI secolo (Bologna: Il Mulino, 1999; reprint 2008). See also: F. Piponnier and P. Mane, Se vêtir au Moyen Âge (Paris: Biro, 1995); O. Blanc, Parades et parures. L'invention du corps de mode à la fin du Moyen Âge (Paris: Gallimard, 1997); Capecchi and Gai, p. 229.

21. Capecchi and Gai, p. 239. 
22. For the issue of women and credit see L. Fontaine, "Women's Economic Spheres and Credit in Pre-Industrial Europe," in B. Lemire et al., eds., Women and Credit: Researching the Past, Refiguring the Future (Oxford: Berg, 2001), pp. 15-32. See also W. C. Jordan, Women and Credit in Pre-Industrial and Developing Societies (Philadelphia: University of Pennsylvania, 1993), pp. 11-49.

23. Archivio di Stato di Urbino, Fondo Monte di Pietà, Libro del depositario 1492-1493. All pawns are registered with an individual number, and for convenience and clarity I will cite references by registration number rather than by folio. For more on the clothing and terminology, see Muzzarelli, Guardaroba medievale.

24. D. Liscia Bemporad, "Il gioiello gotico nell'Italia centro-settentrionale," in Dalla testa ai piedi. Costume e moda in età gotica, ed. L. Dal Prà and P. Peri (Trento: Provincia Autonoma di Trento, 2006), pp. 562-75.

25. ASU, MdP, Libro del depositario 1492-93, \#807, \#828, \#927, \#943, \#1129.

26. ASU, MdP, Libro del depositario 1492-93, \#974, \#1240, \#927, \#903, \#872.

27. ASU, MdP, Libro del depositario 1492-93,\#850. (\#760: "camora turchina usata cum maniche rosse, balza verde, presette de ottone cum una bandella d'oro da collo, tinghiata, forata e machiata"; \#765: "camora de rosato, maniche de veluto negro spelate, prezette 48 de argiento, balza verde vechia e machiata e tinghiata...”).

28. “doi figure anielate pesso once 9 1/2 in uno mucichino." ASU, MdP, Libro del depositario 1492-93, \#994, \#1244. The clothing was measured in braccia; one braccia was approximately 60 centimetres.

29. ASU, MdP, Libro del depositario 1492-93. A "camora usata, tinghiata e forata.... cilestra maniche di rosato e balza verde" brought 50 bolognini (\#1177); a "camora cilestre maniche pavo, balza verde, presette 54 cun uno paro de uncinelli d'argiento" brought 60 bolognini (\# 1176); a "camurra turchina a la fiorentina, maniche de rosato, balza, presette...cordillini rossi e verdi..." brought 80 bolognini (\#741 but see also \#786); a "camorra cilestra maniche rosse, balza verde...cum li gangari d'argiento..." brought 100 bolognini (\# 800).

30. ASU, MdP, Libro del depositario 1492-93, \#857, \#856, \#1226. See also \#768: "paonazzo di grana con maniche di velluto nero, rotte, spelata, macchiata e tinghiata in più luochi." In \#754 a camurra valued at 26 bolognini was described as "de cilestro cum maniche de pavonazzo, balza verde, presette 8 , vecchia e tinghuta in più lochi." This garment was worth as much as \#785: a woman's belt "all'antica, usato con fibbia, puntale, spranghette e campanelle dal peso di tre once." By contrast, \#1230 a "tabarretto di panno nero nostrano foderato (lined) de cilestro," described as stained, used, broken, and covered with holes, was valued at only 22 bolognini. 
31. ASU, MdP, Libro del depositario 1492-93, \#1137 (cape), \#1229 (belt). The belt buckle was "puntale, spranghette 8 in uno sopragietto straciato."

32. ASU, MdP, Libro del depositario 1492-93, \#794, \#1219, \#1154, \#1155). A used sheet of fifteen braccia was worth ten bolognini (\#1237), the same value assigned an $8 \frac{1}{2}$ braccia length of linen (\#1040) or a $13 \frac{4}{4}$ braccia sheet (\#1061).

33. ASU, MdP, Libro del depositario 1492-93, \#973, \#1093, \#1196, \#1076, \#794, \#1034). A $1 \frac{1}{2}$ braccia length of dark green "nostrano" was worth twelve bolognini, while a light black satin would have brought a bit less. A braccia of this last fabric was valued at twelve bolognini (\#1093) while a braccia of dark green "panno di Verona bagniato et cimato" could bring up to 22 bolognini (\#842). A 6 1/2 braccia length of "panno argentino" carried a value of 80 bolognini (\#917) or twelve bolognini per braccia, which was more or less the same as the light black satin. A 40 braccia bolt of "panno turchino di mantova" was worth 95 bolognini (\#871), more or less two bologini per braccia, or the same as thin linen. A twelve braccia length of "fustagno bianco" was priced at eighteen bolognini, or $1 \frac{1}{2} 2$ per braccia (\#887), six braccia of "panno nero nostrano" brought 40 bolognini, or six per braccia (\#777), and $6 \frac{1}{3}$ braccia of "panno nostrano cilestro" was valued at 70 bolognini, or eleven per braccia (\#750).

34. ASU, MdP, Libro del depositario 1492-93. The belts described, in order, are: \#1016, \#769, \#806, \#792, \#785, \#804; the socks (\#746) are described as "scarlattino foderate di bianchetto e rotte sotto la brachetta.” Wrappings for belts: \#952, \#989, \#1047, \#106, \#1088, \#1128, \#1167, \#1193.

35. ASU, MdP, Libro del depositario 1492-93: \#1216, \#753, \#935, \#780. Four silver spoons weighing $4 \frac{3}{4}$ ounces were valued at two florins.

36. ASU, MdP, Libro del depositario 1492-93, \#1103, \#979, \#961, \#948, \#951, \#930.

37. A. E. C. McCants, "Goods at Pawn: The Overlapping Worlds of Material Possessions and Family Finance in Early Modern Amsterdam," Social Science History 31.2 (2007), pp. 213-38.

38. Renata Ago, Una storia degli oggetti nella Roma del Seicento (Roma: Donzelli, 2006), p. xv. On the topic of "Objects" see Oggetti, ed. S. Cavallo and I. Chabot, special issue of Genesis. Rivista della società italiana delle storiche 5.1 (2006).

39. Renata Ago, "Il linguaggio del corpo," in La moda, Storia d'Italia, Annali, 19 (Torino: Einaudi, 2003), pp. 117-47, and particularly "Vestiti e poco altro," pp.119-21.

40. "l'abito non è piccolo argomento della fantasia di chi lo porta," in Baldesar Castiglione, Il libro del Cortegiano, ed. W. Barberis (Torino: Einaudi, 1998), p. 160. 
41. C. Richardson and T. Hamling, eds., Everyday Objects: Medieval and Early Modern Material Culture and its Meanings (Aldershot: Ashgate, 2010). 